\title{
Insulinresistens - kroppens forsvar mot kaloriforgiftning?
}

\author{
Nye hypoteser om patogenesen til type 2-diabetes er blitt fremlagt de siste årene, hvor man ser på insulin- \\ resistens som en fysiologisk beskyttelsesmekanisme mot metabolsk stress, særlig for hjertet.
}

Trond Methi

methi.trond@gmail.com

Per Medbøe Thorsby

Konsekvensen av adaptiv insulinresistens kan være redusert risiko for akutt kardiovaskulær sykdom, men samtidig økt belastning på kroppens andre organer med økt risiko for mikrovaskulær skade. Type 2-diabetes er kanskje prisen kroppen må betale for å overleve i en kaloriforgiftet tilstand? Men hva er egentlig type 2-diabetes?

I det gjeldende paradigmet forårsakes type 2-diabetes av en «arvelig disposisjon, oftest i kombinasjon med overvekt og lite fysisk aktivitet» (1). Sykdommen karakteriseres av nedsatt følsomhet for virkningen av insulin (insulinresistens) og utilstrekkelig insulinproduksjon i forhold til kroppens behov (betacellesvikt), med resulterende hyperglykemi (2). Diagnosen stilles når blodsukkeret når et visst nivå, eksempelvis målt ved langtidsblodsukker HbA1c $\geq 6,5 \%$.

I tradisjonell farmakologisk behandling tar man sikte på å redusere leverens glukoseproduksjon (metformin), øke betacellenes insulinsekresjon (sulfonylurea) eller tilføre insulin gjennom injeksjoner. Det er godt dokumentert at intensiv glykemisk kontroll ved hjelp av disse virkningsmekanismene reduserer risikoen for mikrovaskulær sykdom hos personer med type 2-diabetes samt reduserer symptomene forårsaket av hyperglykemi (1).

\section{Kardiovaskulær effekt av intensiv glykemisk kontroll}

Personer med type 2-diabetes har dobbelt så høy risiko for kardiovaskulær sykdom som normalbefolkningen (3), og dette er også den vanligste dødsårsaken (4). Epidemiologiske studier har vist en sammenheng mellom HbA1c og kardiovaskulære hendelser (5), og en rimelig hypotese har derfor vært at en reduksjon i $\mathrm{HbA} 1 \mathrm{c}$ vil redusere kardiovaskulær risiko, hvilket er tilfellet for personer med type 1-diabetes (6). Evidensgrunnlaget for dette er imidlertid svakt for type 2-diabetes. Metformin har vist en gunstig effekt hos overvektige (7), mens studier med intensiv glykemisk kontroll har vist enten ingen signifikant effekt på kardiovaskulær risiko $(8,9)$, redusert mortalitet av tidlig intensiv behandling etter langtidsoppfølging (10), eller økt risiko for kardiovaskulær død hos pasienter med mer fremskreden sykdom (11). Disse funnene har skapt debatt om verdien av intensiv glykemisk kontroll på risikoen for makrovaskulære hendelser, og hva som er optimal behandling av type 2 -diabetes.

\section{Kaloriforgiftning som årsak til type 2-diabetes?}

Nye hypoteser om patogenesen til type 2diabetes er blitt lansert de siste årene og kan

\section{«Man vil sjelden utvikle sykdommen uten et vedvarende kaloriover- skudd som følge av overspising og fysisk
inaktivitet»}

bidra til å kaste nytt lys over hvorfor resultatene med intensiv glykemisk kontroll i studier har vært lite oppløftende $(12,13)$.

Genetikk er av betydning for hvor predisponert man er for å utvikle type 2-diabetes (2), men man vil sjelden utvikle sykdommen uten et vedvarende kalorioverskudd som følge av overspising og fysisk inaktivitet. Kroppen vil initialt håndtere kalorioverskuddet gjennom økt lagring av fett i fettvev. Dette representerer normal fysiologi ettersom kroppen ønsker å bevare energien til magrere tider. Så lenge man har tilgjengelig lagringskapasitet, kan man fortsette matinntaket uten at metabolsk sykdom induseres. Enkelte har betydelig evne til å lagre energi i subkutant fettvev, og kan ha høy kroppsmasseindeks (BMI, body mass index) med normalt blodsukker. Faktisk har kun $25 \%$ av personer med BMI $\geq 40 \mathrm{~kg} / \mathrm{m}^{2}$ type 2-diabetes (14). Andre har lavere evne til subkutan fettlagring og/eller mer dysfunksjonelle betaceller og vil utvikle metabolsk sykdom ved lavere kroppsmasseindeks. Omkring $15 \%$ av personer med type 2-diabetes har BMI $\leq 25 \mathrm{~kg} / \mathrm{m}^{2}$ (14). Hvis man hemmer evnen til fettlagring hos forsøksdyr, vil de utvikle type 2-diabetes raskere, til tross for lavere kroppsvekt (15). Dette antyder at fettlagringskapasiteten spiller en rolle for hvor disponert man er for å utvikle sykdommen. Hypoteser om hvorfor noen har mer lagringskapasitet enn andre, er blitt diskutert i Tidsskriftet tidligere (16).

Når man ikke lenger klarer å lagre næringsstoffene på en forsvarlig måte, vil metabolske problemer oppstå. Nylig publiserte data antyder at ektopisk lagring av overskuddsenergi utenfor fettvev, særlig i bukspyttkjertelen, står sentralt i utviklingen av type 2-diabetes (17). Karakteristisk for type 2-diabetes er at stadig økende nivåer av glukose, lipider og frie fettsyrer opptrer i systemisk sirkulasjon, hvilket har toksiske effekter på kroppens celler og vev, såkalt glukotoksisitet og lipotoksisitet altså en kaloriforgiftet tilstand. Ettersom dette er en situasjon menneskeheten sjelden har møtt på gjennom evolusjonen har vi ikke utviklet adekvate forsvarsmekanismer for å beskytte oss mot tilstanden. Utviklingen av sykdommen skjer gradvis og kan ta mange tiår.

\section{Insulinresistens som beskyttelsesmekanisme}

Hvis hjertemuskulaturen overbelastes med næringsstoffer, står den i fare for å kollapse metabolsk og vil ikke lenger klare å utføre sin jobb, som er å få hjertet til å slå. En hypotese er derfor at kardiomyocyttene induserer insulinresistens for å beskytte seg mot dette fatale utfallet $(12,13)$. Ulike grader av insulinresistens kan induseres på tilsvarende måte i lever, fettvev og skjelettmuskulatur. Sett i et slikt perspektiv er ikke insulinresistens en del av patogenesen til type 2-diabetes i tradisjonell forstand, altså noe som må motvirkes med stadig høyere insulindoser, men snarere en fysiologisk 
beskyttelsesmekanisme mot intracellulært metabolsk stress.

Når insulinresistens induseres, svarer betacellene riktignok med å produsere mer insulin slik at normalt blodsukker kan opprettholdes. Dette gjør kroppen i stand til å fordele energi spesifikt mellom ulike organer, med eksempelvis økt relativ insulineffekt i fettvev, med økt fettlagring, mens hjertet i større grad er beskyttet fordi økt insulineksponering der matches av nedsatt insulinfølsomhet. For kroppen er dette et valg mellom to onder, fordi forsvaret av hjertet øker belastningen på kroppens andre organer.

Selv om et insulinresistent hjerte i større grad er beskyttet mot kaloriforgiftning, er risikoen for kardiovaskulær sykdom fortsatt forhøyet. Dette skyldes blant annet de mange andre risikofaktorene som følger i kjølvannet av metabolsk sykdom, eksempelvis hypertensjon, dyslipidemi og inflammasjon. Av dette følger aterosklerose som kan forårsake koronarsykdom, med økt risiko for hjerteinfarkt og kardiovaskulær død. Over tid vil også metabolsk overbelastning føre til ektopisk fettlagring i hjertet, såkalt «fatty heart», som er skadelig for dets funksjon. Videre er diabetisk kardiomyopati forbundet med økt risiko for hjertesvikt.

Denne patogenesen står i kontrast til ukontrollert type 1-diabetes hvor man riktignok også har hyperglykemi, relativ hypertensjon og inflammasjon, og derfor forhøyet risiko for kardiovaskulær sykdom. Men ved type 1-diabetes lider ikke kroppen under kalorioverskudd og kaloriforgiftning, slik tilfellet er ved type 2-diabetes. Tvert imot sulter cellene som følge av absolutt insulinmangel, og man ser derfor sjelden insulinresistens.

Insulinresistens kontrolleres presist av intracellulære signaleringsmekanismer og kan induseres av mange ulike forhold og stimuli, f.eks. oksidativt stress, glukokortikoider og hyperinsulinemi (18). Det finnes flere eksempler på at insulinresistens induseres naturlig i kroppen, bl.a. i puberteten og ved graviditet, hvilket man antar skjer for å prioritere energi til henholdsvis hjernens og fosterets utvikling. Det er vist at nedsatt insulinfølsomhet kan induseres hos friske, normalvektige personer allerede etter én måneds overspising med $40 \%$ økning i kaloriinntak , og dette skjer før overvekt er etablert (19). Tilstanden er reversibel med påfølgende kalorirestriksjon, noe som viser at systemet har en betydelig grad av plastisitet, og kan opp- og nedjusteres basert på kroppens energibalanse.

Problemene oppstår imidlertid når kalorioverskuddet opprettholdes over tid. Dette fremprovoserer høyre grad av insulin- resistens i stadig mer metabolsk stressede organer, deriblant fettvev. Når kroppen når sin maksimale lagringskapasitet, er også taket nådd for insulinresistens, og ytterligere betacellekompensasjon med økt insulinproduksjon er nytteløst. Videre hyperinsulinemi kan da være skadelig, eksempelvis for hjertemuskulatur fordi den blir gjenstand for metabolsk overbelastning (12, 13). Sett i lys av dette er det nylig blitt foreslått at «betacellesvikt» i seg selv også kan være en adaptiv fysiologisk forsvarsmekanisme, hvor betacellene ikke nødvendigvis kollapser som følge av overarbeid, men reduserer sin insulinproduksjon aktivt for å beskytte vitale organer og seg selv mot

\section{«Når man ikke lenger klarer å lagre nærings- stoffene på en forsvar- lig måte, vil metabolske problemer oppstå»}

overeksponering av insulin (20). Dette er fortsatt på hypotesestadiet, men det som er klart, er at betacellene står i en prekær stilling: De er både satt til å kontrollere blodsukkeret og respondere på økt blodsukker med insulinutskilling. Når dette ikke lenger fungerer, fordi virkningen av insulin er blitt minimal, vil den resulterende hyperglykemien også kunne skade dem. Ved å redusere sitt eget glukoseopptak, og dermed insulinproduksjonen, vil akutt betacelledød forhindres. Dette kan bidra til å bevare en viss insulinproduksjon og kan derfor forsinke en enda raskere progresjon til alvorlig diabetes. Hvis man utsetter kroppens betaceller for kronisk hyperglykemi under eksperimentelle betingelser, avtar insulinproduksjonen, men betacellene dør ikke, for tilstanden er reversibel hvis man fjerner det hyperglykemiske påtrykket (21). Hvorvidt hypotesene omkring adaptiv betacellesvikt har noe for seg, gjenstår å se, men de er interessante fordi de bryter radikalt med den gjeldende tankegangen om betacellenes rolle i sykdomsutviklingen til type 2-diabetes.

\section{Insulinterapi ved insulinresistens?}

Medikamentell bruk av insulin spiller en vesentlig rolle $\mathrm{i}$ behandlingen av type 2-diabetes, og i flere studier har man undersøkt kardiovaskulære langtidseffekter av insulin, uten at økt risiko er observert $(8,22)$. Insulin er med andre ord en velprøvd og godt validert behandlingsform, som mange personer med type 2-diabetes er avhengige av for å kontrollere blodsukkeret (1).

Det som ikke er blitt studert i tilstrekkelig grad, er bruk av høye insulindoser hos overvektige personer med type 2-diabetes, som er meget insulinresistente, behandlingsresistente og har høy kardiovaskulær risiko. Overstyring av insulinresistens hos slike pasienter kan presse mer energi inn i hjertemuskulatur som allerede lider under metabolsk stress $(12,13)$. ACCORD-studien ble stoppet tidlig på grunn av økt mortalitet i gruppen som fikk intensiv glykemisk behandling (10). Størst risiko for mortalitet så man hos personer med høy HbA1c som ikke fikk forbedret sin glykemiske kontroll, til tross for et intensivt behandlingsregime (23). Man bør utvise forsiktighet hos slike pasienter og kanskje akseptere et mindre intensivt behandlingsmål, fremfor stadig høyere insulindoser?

\section{Livsstilsendringer og kalorirestriksjon}

Ettersom overspising og fysisk inaktivitet er de primære pådriverne $\mathrm{i}$ patogenesen til type 2-diabetes, er livsstilsendringer antagelig den beste terapien for behandling av sykdommen. Dessverre har en rekke studier vist at det er utfordrende å få til varige endringer i levevaner. I Look-AHEAD-studien resulterte de effektene man klarte å oppnå med intensive livsstilsendringer, ikke i redusert kardiovaskulær risiko (24). Resultatet var skuffende med tanke på hva man trodde man skulle oppnå med livsstilsintervensjon. At studien kom negativt ut på «harde» endepunkter ved langtkommen diabetes taler for at de endringer som skjer ved denne sykdommen, er mer omfattende enn det overvekt og lite trening skulle tilsi.

På den annen side oppnådde man en rekke andre positive effekter, eksempelvis vektreduksjon, forbedret glykemisk kontroll, lavere medikamentbruk/behov, reduksjon i søvnapné, forbedret livskvalitet og fysisk form/mobilitet. Videre har andre mindre enkeltstudier vist gode effekter på glykemisk kontroll med livsstilsendringer $(25,26)$. I en studie med overvektige personer med type 2-diabetes så man at kalorirestriksjon hadde betydelig effekt på kroppens metabolisme med tilnærmet normalisering av blodglukose etter kun én uke med kalorirestriksjon, med en diett bestående av $600 \mathrm{kcal}$ pr. dag (26). Etter totalt åtte uker så man en reduksjon av fettinnholdet i lever og bukspyttkjertel, en forbedring av betacellefunksjon og insulinsensitivitet, og at HbA1c gikk fra 7,4\% til 6,0\%. Kalorirestriksjonen reverserte altså den type 2diabetiske tilstanden. Hvorvidt et slikt regime er realistisk å gjennomføre i praksis, 
er en annen sak, og her ligger utfordringen, både for kliniker og pasient.

Det er også oppløftende at større randomiserte studier viser at progresjonen fra nedsatt glukosetoleranse (IGT) til type 2diabetes kan reduseres med opptil $60 \%$ med livsstilsintervensjon $(27,28)$. Bariatrisk kirurgi er et annet eksempel på at kalorirestriksjon normaliserer blodsukkeret raskt og over tid (29), og ser også ut til å kunne ha en gunstig effekt på kardiovaskulær sykdom (30). En hypotese er at dette skyldes at kaloriforgiftningen avtar, hvilket resulterer i redusert insulinresistens og forbedret glukosehomøostase. Det er sågar blitt vist at et regime med kalorirestriksjon tilsvarende det man oppnår ved bariatrisk kirurgi gir samme forbedring $i$ insulinresistens og betacellefunksjon som bariatrisk kirurgi hos personer med type 2-diabetes (31). Disse dataene antyder at kaloriforgiftning har en vesentlig betydning for patogenesen til type 2-diabetes.

Type 2-diabetes utvikles som følge av en positiv kaloribalanse over mange år. Med tanke på at insulinresistens opptrer så tidlig i sykdomsforløpet til type 2-diabetes, og at «betacelledekompensering» markerer starten på en alvorlig metabolsk krise, bør livsstilsendringer med fokus på både økt fysisk aktivitet og kalorirestriksjon stå sentralt spesielt i forebyggingen, og antagelig også i behandlingen av sykdommen. Personer med type 2-diabetes burde informeres om at deres sykdom ikke nødvendigvis er progredierende, men potensielt kan reverseres, $i$ alle fall $i$ den tidlige fasen, hvis man klarer å endre sine levevaner. Igjen understrekes betydningen av individualisert behandling av type 2-diabetes, hvor hver enkelt person må vurderes og behandles i forhold til sitt sykdomsbilde.

\section{Trond Methi (f. 1977)}

er farmasøyt, ph.d. og medisinsk rådgiver hos Lilly Diabetes.

Forfatter har fylt ut ICMJE-skjemaet og oppgir følgende interessekonflikter: Han er ansatt i Eli Lilly Norge.

\section{Per Medbøe Thorsby (f. 1964)}

er ph.d. og seksjonsoverlege ved Hormonlaboratoriet, Oslo universitetssykehus.

Forfatter har fylt ut ICMJE-skjemaet og oppgir følgende interessekonflikter: Han har mottatt honorar fra Norges diabetesforbund, SanofiAventis, Bristol-Myers Squibb, Statens legemiddelverk og Antidoping Norge.

\section{Litteratur}

1. Diabetes - forebygging, diagnostikk og behand ling. Nasjonale faglige retningslinjer. IS-1674. Oslo: Helsedirektoratet, 2009.

2. Thorsby PM. Studies of candidate genes in overweight and diabetes mellitus. Oslo: Universitete i Oslo, 2013

3. Sarwar N, Gao P, Seshasai SR et al. Diabetes mellitus, fasting blood glucose concentration, and risk of vascular disease: a collaborative meta-analysis of 102 prospective studies. Lancet 2010; 375 : 2215-22.

4. Nwaneri C, Cooper H, Bowen-Jones D. Mortality in type 2 diabetes mellitus: magnitude of the evidence from a systematic review and meta-analysis. The British Journal of Diabetes \& Vascular Disease 2013. 13. 192-207.

5. Stratton IM, Adler Al, Neil HA et al. Association of glycaemia with macrovascular and microvascular complications of type 2 diabetes (UKPDS 35): prospective observational study. BMJ 2000; 321 405-12.

6. Nathan DM, Cleary PA, Backlund JY et al. Intensive diabetes treatment and cardiovascular disease in patients with type 1 diabetes. N Engl J Med 2005: 353: 2643-53

7. UK Prospective Diabetes Study (UKPDS) Group. Effect of intensive blood-glucose control with metformin on complications in overweight patients with type 2 diabetes (UKPDS 34). Lancet 1998; 352 $854-65$

8. UK Prospective Diabetes Study (UKPDS) Group. Intensive blood-glucose control with sulphonylureas or insulin compared with conventional treatment and risk of complications in patients with type 2 diabetes (UKPDS 33). Lancet 1998; 352: 837-53.

9. Patel A, MacMahon S, Chalmers J et al. Intensive blood glucose control and vascular outcomes in patients with type 2 diabetes. N Engl J Med 2008. 358: $2560-72$

10. Gerstein HC, Miller ME, Byington RP et al. Effects of intensive glucose lowering in type 2 diabetes. N Engl J Med 2008; 358: 2545-59.

11. Holman RR, Paul SK, Bethel MA et al. 10-year follow-up of intensive glucose control in type 2 diabetes. N Engl J Med 2008; 359: 1577-89.

12. Nolan CJ, Ruderman NB, Kahn SE et al. Insulin resistance as a physiological defense against metabolic stress: implications for the management of subsets of type 2 diabetes. Diabetes 2015; 64: $673-86$.

13. Taegtmeyer $\mathrm{H}$, Beauloye $\mathrm{C}$. Harmancey $\mathrm{R}$ et al. Insulin resistance protects the heart from fuel overload in dysregulated metabolic states. Am J Physiol Heart Circ Physiol 2013; 305: H1693-7.

14. Bays HE, Chapman RH, Grandy S. The relationship of body mass index to diabetes mellitus, hypertension and dyslipidaemia: comparison of data from two national surveys. Int J Clin Pract 2007; 61 $737-47$

15. Wang MY, Grayburn P, Chen S et al. Adipogenic capacity and the susceptibility to type 2 diabetes and metabolic syndrome. Proc Natl Acad Sci U S A 2008; 105: 6139-44

16. Methi T, Thorsby PM. Hvorfor får ikke alle type 2diabetes? Tidsskr Nor Legeforen 2014; 134 $2284-6$

17. Steven S, Hollingsworth KG, Small PK et al. Weigh loss decreases excess pancreatic triacylglycerol specifically in type 2 diabetes. Diabetes Care 2016; 39: $158-65$

18. Hoehn KL, Salmon AB, Hohnen-Behrens C et al. Insulin resistance is a cellular antioxidant defense mechanism. Proc Natl Acad Sci U S A 2009; 106 17787-92.

19. Brands M, Swat M, Lammers NM et al. Effects of a hypercaloric diet on $\beta$-cell responsivity in lean healthy men. Clin Endocrinol (Oxf) 2013; 78: 217-25.
20. Zaccardi F, Webb DR, Khunti K et al. Comment on Nolan et al. Insulin resistance as a physiological defense against metabolic stress: implications for the management of subsets of type 2 diabetes. Diabetes 2015; 64: 673-686. Diabetes 2015; 64 : e35-6.

21. Brunzell JD, Robertson RP, Lerner RL et al. Relationships between fasting plasma glucose levels and insulin secretion during intravenous glucose tolerance tests. J Clin Endocrinol Metab 1976; 42 222-9.

22. Gerstein HC, Bosch J, Dagenais GR et al. Basal insulin and cardiovascular and other outcomes in dysglycemia. N Engl J Med 2012; 367: 319-28.

23. Riddle MC. Effects of intensive glucose lowering in the management of patients with type 2 diabetes mellitus in the Action to Control Cardiovascular Risk in Diabetes (ACCORD) trial. Circulation 2010; 122: $844-6$

24. Wing RR, Bolin P, Brancati FL et al. Cardiovascular effects of intensive lifestyle intervention in type 2 diabetes. N Engl J Med 2013; 369: 145-54.

25. Aas AM, Bergstad I, Thorsby PM et al. An intensified lifestyle intervention programme may be superior to insulin treatment in poorly controlled Type 2 diabetic patients on oral hypoglycaemic agents: results of a feasibility study. Diabet Med 2005; 22: 316-22

26. Lim EL, Hollingsworth KG, Aribisala BS et al. Reversal of type 2 diabetes: normalisation of beta cell function in association with decreased pancreas and liver triacylglycerol. Diabetologia 2011 54: $2506-14$

27. Tuomilehto J, Lindström J, Eriksson JG et al. Prevention of type 2 diabetes mellitus by changes in lifestyle among subjects with impaired glucose tolerance. N Engl J Med 2001; 344: 1343-50.

28. Knowler WC, Barrett-Connor E, Fowler SE et al. Reduction in the incidence of type 2 diabetes with lifestyle intervention or metformin. N Engl J Med 2002; 346: 393-403

29. Mingrone G, Panunzi S, De Gaetano A et al. Bariatric-metabolic surgery versus conventional medical treatment in obese patients with type $2 \mathrm{dia}-$ betes: 5 year follow-up of an open-label, singlecentre, randomised controlled trial. Lancet 2015; 386: $964-73$

30. Eliasson B, Liakopoulos V, Franzén S et al. Cardiovascular disease and mortality in patients with type 2 diabetes after bariatric surgery in Sweden: a nationwide, matched, observational cohort study. Lancet Diabetes Endocrinol 2015; 3: 847-54.

31. Jackness C, Karmally W. Febres $G$ et al. Very lowcalorie diet mimics the early beneficial effect of Roux-en-Y gastric bypass on insulin sensitivity and $\beta$-cell Function in type 2 diabetic patients. Diabetes 2013; 62: 3027-32.

Mottatt 25.3.2016, første revisjon innsendt 9.5. 2016, godkjent 19.5.2016. Redaktør: Ketil Slagstad. 